\title{
Gynaecological infections in paediatric and adolescent gynaecology: a review of recommendations
}

\author{
Katarzyna Plagens-Rotman¹, Michalina Drejza², Witold Kędziaª, Grażyna Jarząbek-Bielecka \\ ${ }^{1}$ Hipolit Cegielski State University of Applied Sciences, Gniezno, Poland \\ ${ }^{2}$ Centre for Sexology and Adolescent Gynaecology, Department of Perinatology and Gynaecology, Poznan University of Medical \\ Sciences, Poznan, Poland \\ ${ }^{3}$ Division of Developmental Gynaecology and Sexology, Department of Perinatology and Gynaecology, Poznan University of Medical \\ Sciences, Poznan, Poland \\ Adv Dermatol Allergol 2021; XXXVIII (5): 734-739 \\ DOI: https://doi.org/10.5114/ada.2021.110084
}

\begin{abstract}
Inflammation within the genital organs in women is an important problem in gynaecology and venereology. Understanding the factors contributing to the inflammatory process and the role of defence mechanisms against their occurrence is important in terms of prevention and treatment. It is especially visible in paediatric gynaecology, where inflammatory diseases of the vulva, dermatoses, injuries and the effects of possible sexual harassment may overlap.
\end{abstract}

Key words: vulvovaginitis, chlamydia trachomatis, gynaecology, dermatology.

\section{Introduction}

Gynaecology (from the Greek gyne = woman) is a science that covers the diagnosis, treatment and prevention of diseases of the female reproductive system. Moreover, gynaecology is often referred to "female diseases" related primarily to the specificity of anatomical identity and physiology of sex. On the other hand, gynaecology of developmental age, called paediatric and adolescent gynaecology, was distinguished from general gynaecology due to differences in the physiology and pathology of the genital organs of patients in developmental age. Paediatric and adolescent gynaecology deals with patients from the neonatal period until reaching maturity [1].

Obstetric and gynaecological care is undoubtedly one of the most important elements in protecting a woman's health. From puberty, characterized by many hormonal changes, to late old age, every woman should receive care depending on her age and health condition. It should be noted, however, that gynaecological examination as the most intimate medical procedure may cause a sense of shame and embarrassment, especially in adolescents or patients with disability [2, 3]. Moreover, many women would face the dilemma of choosing the facility they want to go to, the gender of the doctor and the person participating in the visit; most often peers, friends, sisters. In the case of an adolescent, a visit to a gynaecological office without prior and proper preparation may cause negative experiences, which will result in avoiding subsequent visits. Therefore, it is necessary to prepare a minor or a person with disability well, provide age-appropriate information on the course of the gynaecological examination and the appropriate course of action at that time, including tact and respect for intimacy and human dignity, regardless of origin, degree of impairment or disability.

It is worth noting that only $16 \%$ of women in Poland make their first visit to the Gynaecological Clinic when they begin puberty between the ages of 13 and 15, between the ages of 16 and $19-48 \%$, and over 20 years of age $-21 \%$ of Polish women. The goal of the first gynaecological visit should not only serve to assess the course of the menstrual cycle and to introduce prophylactic protective vaccinations against HPV, but also to educate the minor patient, including on the physiology of the female reproductive system, sexuality and the implementation of various contraceptive methods adapted to the minor's age.

\section{Vulvar and vaginal infections}

The most common gynaecological problem among patients, regardless of age, is vulvovaginitis [4]. In girls,

Address for correspondence: Katarzyna Plagens-Rotman PhD, Hipolit Cegielski State University of Applied Sciences, Gniezno, Poland, 38 ks. kard. S. Wyszyńskiego St, 62-200 Gniezno, Poland, e-mail: plagens.rotman@gmail.com Received: 13.10 .2020 , accepted: 17.01 .2021$. 
especially before the onset of menarche, as much as $75 \%$ of all gynaecological illnesses are vulvovaginitis associated primarily with the age of the child, systemic diseases, as well as with early sexual activity or sexual harassment.

It should be emphasized that low levels of sex hormones and the degree of development of sexual organs make the vagina and the vulva in childhood particularly exposed to exogenous factors. The fragility and delicacy of the vaginal epithelium makes it prone to damage. Moreover, close proximity to the opening of the urethra and anus is an additional factor contributing to the development of infection $[5,6]$. Lack of fatty lining of the labia, pubic hair, small labia and insufficient hygiene of the vulvar area contribute to the development of inflammation of the genital organs [7]. The nutrient medium for bacteria and fungi may also be the residual secretion of the sebaceous and sweat glands located between the labia minora and greater and under the foreskin of clitoris.

In addition, infection occurs through:

- respiratory system - angina and sore throat (Streptococcus spp., Staphylococcus spp.),

- digestive tract - faecal contamination (Enterococcus spp., E. coli),

- urinary system - infections, birth defects (Gram(-)bacilli, Pseudomonas spp.),

- incorrect care processes.

However, among the factors predisposing to the occurrence of fungal infection of the genital organs (about $0.5-1.5 \%$ of cases) in the so-called "hormonal silence" it is necessary to mention [4]:

- diabetes, especially decompensated - in the clinical picture: persistent itching, swelling, redness of the labia, vestibule, perineum and anus are observed; tight skin, swollen mucous membranes, oozing, with numerous cracks,

- long-term antibiotic therapy,

- immunosuppression,

- congenital immunodeficiencies,

- allergic rhinitis,

- allergic diseases,

- a diet rich in simple sugars (i.e. sweets, pastries, sweetened drinks or sweet dairy products, eating large amounts of fruit containing fructose), refined (white) flour bread, white rice, highly processed food (i.e. instant soups, fast food, canned food),

- a diet low in whole grain cereals, natural, unsweetened fermented dairy products, vegetables including pickles, cabbage (a source of lactic acid bacilli), etc.

\section{Parasitic infections [4]}

Pinworms - especially observed in the school age. The clinical picture of pinworm infection is dominated by eczema and scratches, vulvitis due to penetration of female pinworms into the vaginal vestibule, and in older girls even into the uterus. The mucous membranes of the vaginal atrium are congested, and mucus-purulent discharge may come out of the vagina. Infection with pinworms in the presence of genital infections is diagnosed in $9-12 \%$ of girls.

Human worm (Ascaris lumbricoides) is the cause of delayed physical and mental development, increased nervous excitability and insomnia. There are burning and itchy hives on the vulva and perineum with purulentbloody discharge, rhinitis, facial swelling, coughing and bleeding from the upper respiratory tract.

Pubic louse leading to itching and burning, and local inflammation.

\section{Gonorrheal infection}

Another less common infection with gonorrhoea (Neisseria gonorrhoeae) in girls should not be forgotten as a consequence of contact with people infected with gonorrhoea (both symptomatic and asymptomatic) or contact with infected hygiene items or as a result of sexual abuse. The clinical picture shows significant swelling and redness of the vulva. The vaginal part of the cervix is inflamed, and the vaginal discharge is thick, green and purulent, increasing in volume with pressure on the lower abdomen. In addition, enlargement of the lymph nodes is observed.

The main symptoms of vulvovaginitis in girls include: - itching,

- swelling and redness of the labia,

- abnormal vaginal discharge, usually milky yellow or greenish yellow with a putrid, foul odour,

- fissures - a characteristic feature of chronic inflammations,

- erosions, vesicles or epidermal defects within the vulva skin,

- dysuric symptoms (infection of the urethra and periurethral glands) - ascending urinary tract infection, resolving in about $60 \%$ of cases after the vulvovaginitis has been healed $[8,9]$.

Treatment of vulvovaginitis in girls should be a response to the result of a bacteriological examination with an antibiogram:

- in girls with increased local symptoms and/or generalized and persistent infection - general antibiotic therapy, while in mild clinical course of infection - local antibiotic therapy (ointments, creams, drops, stamens, vaginal globules),

- the use of antihistamines,

- eliminating allergenic products from your diet,

- maintaining proper hygiene by frequent washing of the vulva, avoiding long baths, avoiding hot water, taking care of perineal hygiene,

- the use of sit-ins,

- vaginal irrigation (2-3 times a week),

- the use of local soothing agents (olive emulsions),

- wearing loose cotton underwear, eliminating woollen or plastic garments and irritants (intimate hygiene prod- 
ucts, scented soaps, bath liquids), washing underwear in hot water and restoring the physiological flora of the vagina in adolescent girls [10].

\section{Chlamydia trachomatis infection}

Chlamydia trachomatis belongs to the intracellular bacteria that are the most common cause of sexually transmitted infections (STIs) of the Chlamydiae class, Chlamydiales class/Chlamydiae order, Chlamydiaceae family, together with Chlamydia muridarum and Chlamydia Suis [11]. The isolated Chlamydia pneumoniae and Chlamydia trachomatis are pathogenic for humans, and Chlamydia pecorum and Chlamydia psittaci cause infections among animals. According to the latest knowledge, it is postulated to classify all 11 known species of Chlamydiaceae as one genus of Chlamydia [12-15].

Chlamydia trachomatis is a small gram-negative bacterium of $0.2-1.3 / \mu \mathrm{m}$. A characteristic feature of Chlamydia is the intracellular development cycle lasting from 24 to $48 \mathrm{~h}$ with the coexistence of two morphological forms (elementary body and reticulate body) and the formation of cytoplasmic inclusions. Moreover, they are characterized by a granular shape, cell wall structure and the presence of two nucleic acids (DNA and RNA), and some cellular organelles [16].

Chlamydia trachomatis infection occurs through direct contact with the mucosa through sexual, anal or oral contact. Other risk factors include pregnancy, cervical ectopy or the use of hormonal contraception, which may contribute to changes in the vaginal part of the cervix, invasive diagnostic tests or other urogenital infections that facilitate Chlamydia trachomatis infections.

The World Health Organization estimates that more than $50 \%$ of new cases of Chlamydia trachomatis infections come from South-East Asia. On the other hand, the European Centre for Disease Control and Prevention (ECDC) covering 26 countries of the European Union and the European Economic Area, in 2017 reported 409,646 new infections, constituting 146 cases per 100,000 population. In six countries (Iceland, Denmark, Norway, Great Britain, Sweden and Finland), the incidence exceeded 200 cases per 100,000, representing 650, 573, 478, 350 and 263 respectively. Eight countries reported less than 10 cases per 100,000 (Bulgaria, Croatia, Cyprus, Hungary, Luxembourg, Poland, Portugal and Romania). In the age group between the ages of 20 and $24,39.8 \%$ of cases were reported, in the group of 25-34 years olds $-27.3 \%$, and in the group of $15-24$ years old $-61.9 \%$. The highest rates by age and sex were found among women in the age group between 20 and $24(1,370 / 100,000)$ and between 15 and 19 (1,085/100,000). Among men, the highest incidence was in the age group of 20-24 years $(8,777 / 100,000)[17]$.

\section{Clinical image of chlamydia trachomatis infection}

Infection in the urogenital tract is inflammation of the cervix, endometrium and fallopian tubes resulting, among others, from obstruction of the cervical canal, menstrual bleeding and other pathological bleeding, intrauterine procedures or remnants of miscarriage. The symptoms are cervical wall hypertrophy, swollen vesicular lesions, redness, bleeding tendency, tenderness of the endometrium and mucopurulent discharge at the external cervix. In half of the cases, infections of the urethra are diagnosed, and in one quarter of women - only the urethra $[18,19]$.

Inflammation of the urethra in women as the socalled "urethral syndrome" causes pyuria, painful and frequent urination, leukocyturia, pain in the lumbar region, redness and swelling of the external urethra, and the presence of mucopurulent or mucous discharge [20].

The symptoms of chlamydial vaginitis include vaginal discharge as one of the most common symptoms of developing inflammation.

Bartholin gland infection is a secondary infection with cervical secretion containing chlamydia, due to the formation of an abscess by closing the lumen of the gland; it becomes swollen and enlarged. In addition, there is pain that intensifies during movements [18].

\section{Treatment}

Within the urogenital system $[19,21-24]$

Oral doxycycline $100 \mathrm{mg}$ twice daily for 7 days (contraindicated in pregnancy) or oral azithromycin $1 \mathrm{~g}$ as the first-line treatment for chlamydia trachomatis infections.

Oral erythromycin 500 mg twice daily for 7 days or levofloxacin $500 \mathrm{mg}$ once daily for 7 days (contraindicated in pregnancy) or ofloxacin 200 mg twice daily for 7 days (contraindicated in pregnancy) as second-line drugs in the treatment of chlamydia trachomatis infections.

Oral josamycin for 7 days at a dose of $500 \mathrm{mg}$ three times or $1000 \mathrm{mg}$ twice daily for 7 days as a third-line treatment for chlamydia trachomatis infections.

\section{Within the pelvic cavity $[25,26]$}

Treatment on an outpatient basis:

- Ceftriaxone 500 mg by intramuscular route followed by doxycycline $100 \mathrm{mg}$ twice daily by the oral route plus metronidazole $500 \mathrm{mg}$ twice daily for 14 days (level of evidence la, A),

- Ofloxacin 400 mg twice daily in combination with metronidazole $500 \mathrm{mg}$ twice daily for 14 days by oral route (level of evidence $\mathrm{lb}, \mathrm{A}$ ),

- Moxifloxacin $400 \mathrm{mg}$ once daily by the oral route for 14 days (level of evidence la, $A$ ). 
Treatment in a hospital setting:

- $1 \mathrm{~g}$ ceftriaxone by the intramuscular or intravenous route plus doxycycline $100 \mathrm{mg}$ twice daily by the intravenous route/orally administered doxycycline if well tolerated,

- Doxycycline 100 mg twice daily administered orally plus oral metronidazole 500 mg twice daily for 14 days (level of evidence la, A),

- Clindamycin 900 mg three times a day by the intravenous route plus gentamicin $(3-6 \mathrm{mg} / \mathrm{kg}$ as a single daily dose with simultaneous monitoring of renal function) followed by or $450 \mathrm{mg}$ clindamycin $450 \mathrm{mg}$ four times a day to complete 14 days' orally administered doxycycline 100 mg twice a day plus oral metronidazole at $500 \mathrm{mg}$ twice a day to complete 14 days) (level of evidence la, A).

\section{Chlamydia infection in pregnant women and during breastfeeding}

- Oral azithromycin at a dose of $1 \mathrm{~g}$ for 7 days as the firstline treatment for chlamydia trachomatis infections,

- Amoxicillin administered by the oral route for 7 days at a dose of $500 \mathrm{mg}$ three times a day as a second-line treatment for chlamydia trachomatis infections,

- Oral josamycin for 7 days at a dose of 500 mg three times or 1000 mg twice daily for 7 days as a third-line treatment for chlamydia trachomatis infections.

\section{Complications of chlamydia trachomatis infection} $[27,28]$

- incorrect implantation and miscarriages,

- premature births,

- perinatal infections,

- perihepatitis (Fitz-Hugh-Curtis syndrome),

- pelvic inflammatory disease (PID) manifested as lower abdominal pain - usually bilateral, deep dyspareunia, abnormal bleeding (intermenstrual bleeding, postpartum bleeding, menstrual bleeding) as a consequence of cervicitis and endometritis, vaginal or cervical discharge associated inflammation of the cervix, endometrium or vaginal bacteria [26],

- Sexually Acquired Reactive Arthritis (SARA) syndrome,

- interstitial tubular nephritis syndrome,

- proctitis,

- inclusion conjunctivitis.

\section{Human papillomavirus (HPV)}

Human papillomavirus (HPV) belongs to the Papillomaviridae family and is one of the most common sexually transmitted viruses.

A characteristic feature of HPV is a strong tropism towards squamous multilayered epithelium, especially around the genital area, mouth, throat and skin. Cells are infected in the basal layer of the squamous epithelium, and their full life cycle takes place only in differentiated keratinocytes [29, 30].

It is assumed that the greatest number of HPV infections is observed in the first years of sexual intercourse, and the risk of infection increases significantly with the number of sexual partners, early sexual debut, history of sexually transmitted infections, or with the use of oral contraceptives. Another risk factor is cigarette smoking and inflammation of the vagina and vulva.

Infection with HPV in the majority of cases does not cause symptoms, and may disappear spontaneously with a normal immune response within 6 months to 2 years. However, it should be noted that some infections accompanied by disturbed immune mechanisms or under the influence of other factors, may become persistent and cause carcinogenesis in cervical epithelial cells, identifying E6 and E7 proteins encoded by viral genes, acting as oncogenes responsible for neoplastic transformation of the cervical epithelial cells.

Testing for the presence of E6 and E7 HPV mRNA transcripts, which have a greater diagnostic value than those for viral DNA, allows to detect the beginning of the carcinogenesis process by detecting persistent infections, not only those active at the time of the test. The presence of mRNA in the cells of the cervical epithelium indicates a high risk of developing dysplasia and/or cervical cancer within several years [31-33].

In Poland, according to the National Preventive Vaccination Programme, HPV vaccinations are recommended especially for adolescents before sexual initiation, but they are not financed by the national health services.

According to the recommendations of the Polish Society for the Prevention of HPV Infections regarding the use of HPV vaccines, it is recommended to:

- vaccinate girls aged 12-15; girls from 9 years of age (quadrivalent vaccine) and 10 years of age (bivalent vaccine),

- boys from 9-15 years of age (quadrivalent vaccine) can also be vaccinated,

- vaccination of girls and women aged $16-25 / 26$ years before exposure to HPV infection $[34,35]$.

The Polish Paediatric Society (PTP) together with the Polish Society for the Prevention of HPV Infections (PTPZ$\mathrm{HPV}$ ) recommend HPV vaccination as the mandatory vaccination in the vaccination schedule. Silgard should be administered in the following algorithm: 1 day, 2 months, and 6 months after the first vaccination, while Cervarix -1 day, 1 month and 6 months after the first vaccination [36-38].

\section{Summary}

Inflections within the genital organs in girls and women is an important problem in gynaecology and venereology. Understanding the factors contributing to the inflammatory process and the role of defence mecha- 
nisms against their occurrence is important in terms of prevention and treatment.

Considering the large variety of symptoms reported by young patients, clinical diagnostics is difficult and requires extensive experience on the part of both the gynaecologist and the venereologist.

\section{Conflict of interest}

The authors declare no conflict of interest.

\section{References}

1. Jarząbek-Bielecka G, Bielecki M, Buks J, et al. Operational and conservative methods of dealing in gynecology. Pol Przegl Nauk Zdrowiu 2015; 2: 89-92.

2. Ackerson K, Preston S. A decision theory perspective on why women do or do not decide to have cancer screening: systematic review. J Adv Nurs 2009; 65: 1130-40.

3. Burgis JT, Bacon JL. Communicating with the adolescent gynecology patient. Obstet Gynecol Clin North Am 2003; 30 251-60.

4. Boroch J, Jarząbek-Bielecka G, Mizgier M, et al. Selected dermatological and gynecological problems with regard to some dietary aspects in girls. Med Rodz 2018; 21: 344-8.

5. Joishy M, Ashtekar C, Jain A, et al. Do we need to treat vulvovaginitis in prepubertal girls? B J Med 2005; 330: 186-8.

6. Olejek A, Kellas-Ślęczka S, Kozak-Darmas I, et al. Vulvovaginitis in young girls. Ginekol Pol 2009; 80: 931-4.

7. Filipp E, Tarnowska-Mądra U, Pawłowska A, et al. Stany zapalne sromu i pochwy u dziewcząt przed menarche. Gin Prakt 2005; 84: 69-72.

8. Pierce A, Hart C. Vulvovaginitis: causes and management. Arch Dis Child 1992; 67: 509-12.

9. Peak S, Merritt D, Mallory S. Pruritus vulvae in prepubertal children. J Am Acad Dermatol 2001; 44: 795-802.

10. Casey RK, Veronica Gomez-Lobo V. Częste choroby sromu u dziewcząt. Komentarz dr hab. Agnieszki Drosdzol-Cop. Ginekol Dypl 2014; 16: 50-8.

11. Lagkouvardos I, Weinmaier T, Lauro FM, et al. Integrating metagenomic and amplicon databases to resolve the phylogenetic and ecological diversity of the Chlamydiae. ISME 2014; 8: 115-25.

12. Sachse K, Bavoil PM, Kaltenboeck B, et al. Emendation of the family Chlamydiaceae: proposal of a single genus, Chlamydia, to include all currently recognized species. Syst Appl Microbiol 2015; 38: 99-103.

13. Subtil A, Collingro A, Horn M. Tracing the primordial Chlamydiae: extinct parasites of plants? Trends Plant Sci 2014; 19: 36-43.

14. Bavoil P, Kaltenboeck B, Greub G. In Chlamydia veritas. Pathog Dis 2010; 67: 89-90.

15. Stephens RS, Myers G, Eppinger M, Bavoil PM. Divergence without difference: phylogenetics and taxonomy of Chlamydia resolved. FEMS Immunol Med Microbiol 2009; 55: 115-9.

16. Pannekoek Y, Qi-Long Q, Zhang YZ, van der Ende A. Genus delineation of Chlamydiales by analysis of the percentage of conserved proteins justifies the reunifying of the genera Chlamydia and Chlamydophila into one single genus Chlamydia. Pathog Dis 2016; 74: ftw071.

17. European Centre for Disease Prevention and Control: Chlamydia infection Annual Epidemiological Report for 2017.
https://ecdc.europa.eu/sites/portal/files/documents/AER for_2017-chlamydia-infection.pdf (Accesssed: 28 August 2019).

18. Buxton D, Anderson IE, Longbottom D, et al. Ovine chlamydial abortion: characterization of the inflammatory immune response in placental tissues. J Comp Path 2002; 127: 133-41.

19. Lanjouw E, Ouburg S, de Vries HJ, et al. Background review for the '2015 European guideline on the management of Chlamydia trachomatis infections'. Int J STD AIDS 2015; 24 : 0956462415618838.

20. Haggerty CL, Gottlieb SL, Taylor BD, et al. Risk of sequelae after Chlamydia trachomatis genital infection in women. J Infect Dis 2010; 201 (Suppl 2): S134-55.

21. Kong FY, Tabrizi SN, Law M, et al. Azithromycin versus doxycycline for the treatment of genital Chlamydia infection: a meta-analysis of randomized controlled trials. Clin Infect Dis 2014; 59: 193-205.

22. Páez-Canro C, Alzate JP, González LM, et al. Antibiotics for treating urogenital Chlamydia trachomatis infection in men and non-pregnant women. Cochrane Database Syst Rev 2019; 25: CD010871.

23. Peuchant O, Lhomme E, Kręt $M$, et al. Randomized, openlabel, multicenter study of azithromycin compared with doxycycline for treating anorectal Chlamydia trachomatis infection concomitant to a vaginal infection (CHLAZIDOXY study). Medicine 2019; 7: e14572.

24. Pandhi D, Sonthalia S. Human papilloma virus vaccins: current scenario. Indain J Sex Transm Dis 2011; 32: 75-85.

25. Judlin P, Liao Q, Reimnitz P, et al. Efficacy and safety of moxifloxacin in uncomplicated pelvic inflammatory disease: the MONALISA study. Br J Obstet Gynaecol 2010; 117: 1475-84.

26. Ross J, Guaschino S, Cusini M, Jensen J. 2017 European guideline for the management of pelvic inflammatory disease. Int J STD AIDS 2018; 29: 108-14.

27. Kelly H, Coltart CEM, Pant Pai N, et al. Systematic reviews of point-of-care tests for the diagnosis of urogenital Chlamydia trachomatis infections. Sex Transm Infect 2017; 93 (Suppl 4): S22-30.

28. Smelov V, Thomas P, Ouburg S, Morré SA. Prevalence of genital Chlamydia trachomatis infections in Russia: systematic literature review and multicenter study. Pathog Dis 2017; 75: doi: 10.1093/femspd/ftx081.

29. Kosińska KW, Lubawa WM, Szczęśniak M, et al. Assessment of women's awareness about reproductive and breast cancers. J Med Sci 2017; 86: 23-9.

30. Plagens-Rotman K. Rola pielęgniarki, lekarza i farmaceuty w zintegrowanym podejściu do pacjentek ze zdiagnozowanym rakiem szyjki macicy. Farmakoekonom Szpitalna 2020; 49: 53-7.

31. Castellsagué X, Paavonen J, Jaisamrarn U, et al. Risk of first cervical HPV infection and pre-cancerous lesions after onset of sexual activity: analysis of women in the control arm of the randomized, controlled PATRICIA trial. BMC Infect Dis 2014; 14: 551.

32. Eide ML, De Baque H. HPV detection methods and genotyping techniques in screening for cervical cancer. Ann Pathol 2012; 32: 15-23.

33. Skinner RS, Wheeler CM, Romanowski B, et al. Progression of HPV infection to detectable cervical lesions or clearance in adult women: analysis of the control arm of the VIVIANE study. Int J Cancer 2016; 138: 2428-38.

34. Cianciara D, Dudzik K, Rdzany R, et al. Szczepienia przeciwko HPV w samorządowych programach zdrowotnych. Porów- 
nanie z programami szczepień w innych krajach europejskich. Hygeia Public Health 2015; 50: 112-8.

35. Wysocki J, Jackowska T, Małecka I, et al. Szczepienia przeciw wirusowi brodawczaka ludzkiego (HPV) u dzieci i młodzieży jako element profilaktyki raka szyjki macicy. Pediatr Pol 2012; 87: 637-44.

36. Arie S. Global HPV vaccination. BJM 2011; 342: d1042.

37. Gravitte PE. The know unknowns of HPV natural history. J Clin Invest 2011; 121: 4593-9.

38. Pandhi D, Sonthalia S. Human papilloma virus vaccins: current scenario. Indain J Sex Transm Dis 2011; 32: 75-85. 